\title{
PEMBAHARUAN HUKUM KONTRAK INDONESIA DALAM KERANGKA HARMONISASI HUKUM KONTRAK ASEAN
}

(Indonesian Contract Law Reform on the Legal Framework Contract ASEAN Harmonization)

\author{
Subianta Mandala \\ Badan Pembinaan Hukum Nasional Kementerian Hukum dan HAM \\ Jl. Mayjen. Soetoyo Cililitan Jakarta Timur
}

Naskah diterima: 18 Mei 2012; revisi: 12 Juli 2012; disetujui: 23 Juli 2012

\begin{abstract}
Abstrak
Pembentukan Masyarakat Ekonomi ASEAN pada tahun 2015 telah mendorong Negara Anggota ASEAN untuk mereformasi undang-undang mereka. Ini adalah momentum yang baik bagi Indonesia untuk mereformasi hukum kontrak dan pada saat yang sama untuk mencapai komitmen ASEAN untuk harmonisasi hukum ASEAN. Dalam tulisan ini akan dibahas, pendekatan hukum dapat diambil oleh Indonesia dalam upaya untuk mereformasi hukum kontrak sehingga konsisten dengan tujuan harmonisasi ASEAN hukum; dan seberapa luas atau apa lingkup substansi untuk dimasukkan dalam undangundang untuk bisa menjadi undang-undang baru yang kompatibel dengan hukum kontrak Negara ASEAN lainnya. Tulisan ini menggunakan metode penelitian hukum normatif dengan analisa kualitatif. Kesimpulan yang diperoleh dari penelitian ini adalah bahwa pendekatan yang diambil untuk mereformasi hukum kontrak Indonesia saat ini adalah dengan menggunakan instrumen hukum internasional seperti Konvensi PBB tentang Kontrak untuk Penjualan Barang Internasional (CISG) 1980 dan Prinsip UNIDROIT Kontrak Komersial Internasional (UPICCS) sebagai referensi untuk hukum kontrak Indonesia yang baru. Sedangkan lingkup substansi yang akan direformasi terbatas pada prinsip-prinsip umum dan aturan hukum kontrak internasional dan ketentuan untuk penjualan barang. Untuk mempercepat reformasi, penulis menunjukkan bahwa hukum kontrak diprioritaskan dengan memasukkannya ke dalam Program Hukum Nasional (Prolegnas) dari periode 2015-2019. Kata kunci: hukum kontrak, harmonisasi hukum, ASEAN.
\end{abstract}

\begin{abstract}
The establishment of ASEAN Economic Community by 2015 has encouraged ASEAN Member States to reform their laws for harmonization, including contract law. This is a good momentum for Indonesia to reform its contract law and at the same time to achieve ASEAN commitment for ASEAN legal harmonization. Having said that, the questions are (1) what legal approach can be taken by Indonesia in its effort to reform its contract law so that it is consistent with the objective of ASEAN legal harmonization, (2) how broad or what the scope of substance to be included in the new law can be so that the new law will be compatible with the contract laws of other ASEAN Countries. To answer those questions, minor research has been conducted. A method of normative legal research is used to collect data which is mainly from books, academic drafts, national legislation and international treaties (secondary data). Those data is, then, analyzed using qualitative method. In conclusion, (1) the approach taken to reform the current Indonesian contract law is by using international legal instruments such as United Nations Convention on Contracts for the International Sale of Goods (CISG) 1980 and UNIDROIT Principles of International Commercial Contracts (UPICCs) as references for the new Indonesian contract law, (2) the scope of the substance to be reformed is restricted to the general principles and rules of international contract law and provisions for sale of goods. To speed up the reform, the writer suggests that contract law be prioritized by putting it into the National Legal Program (Prolegnas) of 2015-2019 period.
\end{abstract}

Keywords: contract law, legal harmonization, ASEAN. 


\section{A. Pendahuluan}

Hukum kontrak merupakan bidang hukum yang sangat penting di era globalisasi terutama dalam mendukung kegiatan di sektor perdagangan dan transaksi bisnis internasional. Lahirnya kesepakatan perdagangan di antara Negaranegara di dunia, antara lain GATT/WTO, NAFTA, APEC, EU dan AFTA dan lainnya turut mempercepat globalisasi ekonomi dan perdagangan. Proses globalisasi ini pada gilirannya memaksa Negara-negara di dunia untuk membuka diri.

Perkembangan penting yang terjadi di dalam ASEAN baru baru ini adalah ditanda-tanganinya Piagam ASEAN pada bulan Nopember 2007 yang mengindikasikan komitmen Negara-negara ASEAN untuk memperkuat kerjasama regional melalui pembentukan masyarakat ASEAN (ASEAN Community), termasuk Masyarakat Ekonomi ASEAN, yang diharapkan terwujud pada tahun 2015. ${ }^{1}$

Dalam rangka mewujudkan suatu Masyarakat Ekonomi ASEAN yang lebih terintegrasi tersebut maka peran hukum akan semakin sentral. Pengembangan hukum perdagangan ASEAN sedang menjadi kajian dan pembahasan secara intensif di ASEAN. Salah satu bidang hukum yang mendapat prioritas di ASEAN untuk diharmoniskan adalah hukum kontrak dagang Internasional. Hukum kontrak (internasional) akan menjadi bidang hukum yang semakin penting dalam upaya mendukung kegiatan perdagangan dan transaksi bisnis dalam Masyarakat
Ekonomi ASEAN karena aktifitas perdagangan dan transaksi bisnis diwujudkan dalam bentuk kontrak-kontrak dagang internasional.

Hukum kontrak Indonesia sekarang ini, yang menganut tradisi civil law, masih berpedoman pada aturan yang merupakan warisan dari pemerintahan kolonial Hindia Belanda, yaitu KitabUndang-Undang HukumPerdata(KUHPerd) atau Burgerlijk Wetboek (BW) khususnya Buku III tentang Perikatan dan lebih khusus lagi diatur dalam Bab II tentang Perikatan yang Lahir dari Perjanjian. Hukum kontrak Indonesia adalah produk hukum yang sudah out of date dan belum mengakomodir perkembangan yang ada, terutama menyangkut kontrak-kontrak dagang internasional. $^{2}$

Belanda sendiri, sebagai negara yang membawa $B W$ ke Indonesia sudah mengganti dengan yang baru, yaitu Nieuw Burgerlijk Wetboek (NBW) yang muatannya sudah sangat berbeda dengan $B W$. NBW yang saat ini berlaku di Belanda sebagai The Dutch Civil Code sudah jauh lebih maju baik dari segi substansi maupun sistematika sebagai koreksi atas kelemahankelemahan yang terdapat dalam $B W$.

Gagasan untuk memperbarui hukum kontrak Indonesia sudah lama diperbincangkan. Berbagai konsep mengenai hukum kontrak/perjanjian/ perikatan yang baru pernah dibuat, baik dalam bentuk kajian/penelitian ilmiah maupun naskah akademik, dan bahkan sudah dalam bentuk rancangan undang-undang. Namun, keinginan

$1 \quad$ Piagam ASEAN ditanda-tangani oleh 10 Kepala Negara/Pemerintahan ASEAN tanggal 20 Nopember 2007 pada KTT ke-13 di Singapore dan mulai berlaku efektif tanggal 15 Desember 2008 setelah kesepuluh Negara anggota ASEAN menyampaikan instrument ratifikasi. Piagam ASEAN utamanya berisi keinginan untuk membentuk Masyarakat ASEAN yang ditopang oleh 3 pilar Masyarakat ASEAN, yaitu: Masyarakat Politik-Keamanan ASEAN, Masyarakat Ekonomi ASEAN, dan Masyarakat Sosial Budaya ASEAN. Untuk mewujudkan ke 3 pilar tesebut, ASEAN juga telah mengeluarkan blueprint untuk masing-masing pilar tersebut.

2 Lihat Taryana Sunandar, Prinsip Prinsip UNIDROIT Sebagai Sumber Hukum Kontrak dan Penyelesaian sengketa (Jakarta: Sinar Grafika, 2004), hlm. 3. 
untuk mewujudkan sebuah hukum perjanjian/ kontrak yang baru belum bisa terwujud sampai kini.

Momentum untuk menghidupkan kembali gagasan memperbarui atau memodernisasi hukum kontrak Indonesia telah tiba ketika ASEAN mengambil inisiatif untuk melakukan harmonisasi di bidang hukum perdagangan, termasuk hukum kontrak.

\section{B. Permasalahan}

Berdasarkan latar belakang yang diuraikan di atas, maka tulisan ini akan membahas permasalahan-permasalahan sebagai berikut:

1. Bagaimanakah metoda pendekatan yang paling efektif untuk memperbaharui hukum kontrak / hukum perjanjian yang diatur dalam Buku III KUHPerdata dalam rangka mendukung terwujudnya harmonisasi hukum kontrak ASEAN.

2. Sampai sejauh manakah substansi perubahan hukum kontrak yang harus diwujudkan sehingga hukum kontrak Indonesia masa depan juga sekaligus harmonis dengan hukum kontrak Negara-negara anggota ASEAN;

\section{Metodole Penelitian}

Untuk mengkaji permasalahan di atas, penulis menggunakan motode penelitian hukum normatif. Penelitian ini menitikberatkan pada studi literatur (data sekunder). Studi literatur (kepustakaan) dilakukan untuk mendapatkan dan mengkaji sumber-sumber tertulis yang meliputi: (1) bahan hukum primer yaitu Buku III KUHPerdata, dan perjanjian internasional seperti United Nations Convention on Contracts for the International Sale of Goods (CISG) 1980 dan peraturan perundang-undangan nasional dan konvensi internasional lainnya yang terkati, (2) bahan hukum sekunder yakni bahan-bahan yang erat hubungannya dengan bahan hukum primer dan dapat membantu menganalisa dan memahami bahan hukum primer, seperti Naskah Akademik dan Rancangan Undang-undang Hukum Perikatan, Naskah Akademik tentang Kontrak di Bidang Perdagangan. Disamping itu, sebagai bahan hukum sekunder, penulis juga menggunakan model law atau Legal Principles seperti UNIDROIT Principles of International Commercial Contracts. Bahan hukum sekunder lainnya yang digunakan adalah buku, karya tulis/paper/makalah dan hasil penelitian yang berkaitan dengan hukum kontrak dan harmonisasi hukum.

Keseluruhan data yang diperoleh baik dari bahan primer maupun sekunder dianalisis secara kualitatif dan diberikan penggambaran (deskripsi) secara mendalam mengenai pendekatan dan substansi pembaruan hukum kontrak Indonesia. Kesimpulan diambil berdasarkan pada metoda penalaran deduktif dan Induktif.

\section{Pembahasan}

1. Metoda Pendekatan Yang Paling Efektif Untuk Memperbarui Hukum Kontrak

\section{a. Upaya Pembaruan Hukum Kontrak Indonesia}

Perubahan hukum kontrak Indonesia adalah urgen dan perlu diprioritaskan. ${ }^{3}$ Dikatakan urgen dan perlu diprioritaskan terutama karena negara kita telah berada di tengah perkembangan perdagangan bebas dan global yang tidak dapat begitu saja dielakkan atau dihindari. Dalam

Dalam Prolegnas 2010-2014, hukum kontrak belum masuk dalam daftar RUU Prioritas. 
posisinya sebagai salah satu negara ASEAN yang telah bertekad untuk berkembang sebagai sebuah rule based regional organization dan menuju sebuah Masyarakat Ekonomi ASEAN, Indonesia akan dituntut untuk memberikan lebih banyak komitmen untuk berperan serta dalam upaya pengembangan perekonomian regional dan inter-regional (dengan mitra-mitra ASEAN di berbagai region).

Sebagaimana telah disinggung di bagian Pendahuluan tulisan ini, usaha-usaha untuk mengganti, merombak dan memperbarui hukum kontrak Indonesia sudah berlangsung lama. Gagasan Awal untuk melakukan pembaruan hukum kontrak nasional diajukan oleh Wirjono Projodikoro yang menurut beliau hukum perjanjian adalah satu satunya bagian hukum perdata yang segera dapat dilakukan kodifikasi karena bidang hukum tersebut dianggap cukup netral.

Semangat yang mengedepan dalam diri Wirjono Projodikoro adalah menghidupkan lembaga perjanjian dalam Hukum Adat. Hukum Adat pada hakikatnya hukum yang berbeda di berbagai daerah. Namun demikian, perbedaan yang ada dalam Hukum Adatini, khususnya Hukum Perjanjian, tidak begitu tajam bila dibandingkan dengan Hukum Waris atau Perkawinan yang sarat akan nilai nilai. Wirjono Projodikoro secara tegas menyatakan sebagai berikut: ${ }^{4}$

"Lain halnya dengan Hukum Perjanjian, yang ternyata tidak memperlihatkan begitu banyak perbedaan yang mendalam di antara hukum yang berlaku bagi pelbagai golongan dan daerah di Indonesia. Maka dari itu, saya berkeyakinan, bahwa dengan sekuat tenaga dan kemauan yang baik dapat diusahakan agar dalamjangka pendek diketemukan suatu perumusan Hukum Perjanjian di Indonesia, yang dapat ditetapkan berlaku bagi segenap warga negara Indonesia. Untuk permulaan, dapat dimulai dengan bagian umum dari Hukum Perjanjian itu".

Pada tahun 1974 pernah disusun sebuah Rancangan Undang-Undang (RUU) Hukum Perikatan yang diketui oleh Prof. R. Soebekti. Sistimatika RUU ini mengikuti sistimatika Buku III KUHPerdata. ${ }^{5}$ Tercatat pula pada tahun 1992 BPHN pernah membentuk Tim Kerja Penyusunan Naskah Akademis Peraturan Perundangundangan tentang Kontrak di Bidang Perdagangan yang diketuai oleh Prof. Sunaryati Hartono. ${ }^{6}$ Dalam Naskah Akademik tersebut dibahas mengenai asas-asas hukum kontrak, kontrak baku, kontrak pemerintah, dan kontrak internasional.

Upaya pembaruan hukum kontrak terakhir pernah dilakukan oleh R. Setiawan melalui penyusunan Naskah Akademik Peraturan Perundang-undangan tentang Perikatan pada tahun 1994. ${ }^{7}$ R. Setiawan berpendapat bahwa sebagian ketentuan Hukum Perikatan dalam KUHPerdata sudah tidak sesuai lagi dengan perkembangan yang ada, dan sebagian yang lain masih relevan untuk dipertahankan. Seiring dengan era globalisasi yang menyentuh hampir semua aspek kehidupan masyarakat indonesia, R. Setiawan secara tegas menyatakan bahwa bidang hukum, khususnya Hukum Perjanjian, mulai terkena pengaruh apa yang dikenal sebagai Convention Law dan Community Law. Lebih lanjut,

Wirjono Prodjodikuro, Asas-Asas Hukum Perjanjian (Bandung: Mandar Madju, 2000), hlm. 160.

Lihat Naskah Akademik Peraturtan Perundang-undangan tentang hukum Perikatan, BPHN, Departemen Kehakiman RI, 1976/1977.

Naskah Akademik tentang Kontrak di Bidang Perdagangan, BPHN Departemen Kehakiman, 1994.

Taufiqurrahman, Karakter Pilihan Hukum, Kajian tentang Lingkup Penerapan the United Nations Convention on Contracts for the International Sale of Goods (CISG) 1980 (Surabaya: Bayumedia, 2010), hlm. 350. 
R. Setiawan menyatakan bahwa Hukum Perikatan dalam konteks internasional dihadapkan pada masalah yang berkaitan dengan harmonisasi hukum.

Ketiga naskah akademik RUU tersebut di atas yang dimaksudkan sebagai upaya pembaruan hukum nasional di bidang Hukum Kontrak tampaknya masih terfokus pada pengaturan terhadap transaksi-transaksi yang bersifat domestik. Sekalipun perkembanganperkembangan internasional turut juga mempengaruhi perancang dalam menyusun naskah RUU tersebut, sebagaimana R. Setiawan, tetapi rumusan naskahnya masih bermuara pada kepentingan-kepentingan domestik. Eksistensi kontrak-kontrak internasional dalam lalu-lintas perdagangan belum mendapat sentuhan yang berarti secara konseptual. ${ }^{8}$

Upaya menghidupkan kembali gagasan pembaruan hukum kontrak Indonesia timbul belakangan ini terkait dengan perkembangan yang terjadi pada organisasi ASEAN - yaitu keinginan untuk mewujudkan suatu masyarakat ASEAN yang lebih terintegrasi secara ekonomi pada tahun 2015. Dalam rangka Masyarakat Ekonomi ASEAN tersebut, pejabat tinggi hukum ASEAN yang tergabung dalam ASEAN Senior Officials Meetings (ASLOM) dalam program kerjanya telah mencanangkan untuk melakukan harmonisasi hukum dagang ASEAN, termasuk hukum jual beli barang internasional (international sale of goods). ${ }^{9}$

\section{b. Harmonisasi Hukum Kontrak ASEAN}

Pembentukan Masyarakat Ekonomi ASEAN pada tahun $2015^{10}$ dan juga dalam rangka melaksanakan ASEAN Free Trade Area (AFTA) $)^{11}$ menjadikan hukum kontrak sebagai bidang hukum yang sangat penting dalam mendukung kegiatan di sektor perdagangan dan transaksi bisnis internasional dikawasan ASEAN. Menyatukan hubungan antara para pihak dalam lingkup ASEAN bukanlah persoalan yang sederhana. Hal ini menyangkut perbedaan sistem, paradigma, dan aturan hukum yang berlaku sebagai suatu aturan yang bersifat memaksa untuk dipatuhi oleh para pihak di masing-masing negara.

Negara Negara ASEAN yaitu: Indonesia, Thailand dan Vietnam dapat digolongkan penganut sistem hukum civil law, sedangkan Singapore, Malaysia dan Brunei Darussalam adalah penganut sistem hukum common law. ${ }^{12}$

Perbedaan sistem hukum sebagaimana disebutkan di atas memberikan pengaruh yang signifikan kepada masing-masing negara dalam pembentukan hukum (undang-undang) yang mengatur mengenai kontrak baik dari aspek formil maupun materiilnya. Hukum kontrak pada

8 bid. hlm. 351.

9 Selain hukum jual beli barang internasional, bidang hukum dagang lain yang diharmonisasikan adalah international commercial arbitration, government procurement, dan e-commerce.

10 Untuk membantu pencapaian integrasi regional ASEAN yang diinginkan- yaitu Masyarakat ASEAN pada tahun 2015, telah dikeluarkan blueprint yang berisi langkah-langkah strategis yang harus dilaksanakan oleh ASEAN. Salah satu strategi yang disebutkan dalam blueprint adalah melakukan kerjasama untuk mengembangkan strategi-strategi untuk memperkuat supremasi hukum (rule of law) dan sistem peradilan (judiciary system) serta infrastruktur hukum (legal infrastructure) di ASEAN.

11 AFTA diberlakukan secara penuh untuk 6 negara ASEAN sejak 1 Januari 2002 dengan fleksibilitas (terhadap produk-produk tertentu tarifnya masih diperkenankan lebih dari 0-5\%). Target tersebut diterapkan untuk 6 negara ASEAN sedangkan untuk negara baru: Vietnam (2006); Laos dan Myanmar (2008); dan Cambodia (2010).

12 Lihat Allan D. Rose A.0, "The Challenges for Uniform Law in the Twenty-First Century", Uniform Law Review, NSVol.1, (2005):9-25. 
kenyataanya sangat beragam karena adanya perbedaan sistem hukum di masing-masing negara tersebut. ${ }^{13}$ Kalaupun ada persamaan, hanya terkait dengan prinsip-prinsip umum yang belum dapat diaplikasikan secara nyata sebagai pedoman dalam pembentukan kontrak internasional yang lingkup objeknya begitu luas, sedangkan aturan-aturan yang sifatnya substantif berbeda di masing-masing negara. Kondisi seperti ini tentunya tidak kondusif bagi aktivitas perdagangan dan bisnis ASEAN. Adanya perbedaan aturan di masing-masing negara akan menghambat terlaksananya transaksi bisnis internasional yang menghendaki kecepatan dan kepastian.

Pembahasan menyangkut harmonisasi hukum dagang ASEAN, termasuk di dalamnya harmonisasi hukum jual beli barang internasional, sedang dilakukan oleh ASEAN Senior Law Officials Meeting (ASLOM), sebuah badan sektoral di bawah ASEAN yang keanggotaannya terdiri dari para pejabat tinggi hukum ASEAN. Kelompok kerja ASLOM (ASLOM Working Group) yang bertugas mengkaji dan membahas harmonisasi hukum kontrak telah merekomendasikan kepada negara- negara ASEAN untuk mengubah atau membuat hukum kontrak yang sesuai dengan aturan yang berlaku secara universal atau best practices. Secara spesifik, ASLOM merekomendasikan untuk mengadopsi prinsip-prinsip hukum kontrak internasional yang ada dalam United Nations Convention on Contracts for the International Sale of Goods (CISG) 1980 dan UNIDROIT Principles of International Commercial Contracts (UPICCS) pada tahun 1994 yang kemudian telah direvisi pada tahun $2010 .{ }^{14}$

\section{c. MetodaPendekatan:CISG dan UNIDROIT Principles}

Dengan argumentasi bahwa pembaruan hukum kontrak Indonesia harus sejalan dengan arah perkembangan harmonisasi hukum kontrak ASEAN, maka pendekatan yang dilakukan dalam perubahan hukum perjanjian yang terdapat dalam Buku III KUHPerdata harus sejalan dengan rekomendasi yang dijalankan oleh ASEAN. Diantara berbagai pendekatan yang telah dikaji15, ASEAN merekomendasikan agar Negaranegara anggota ASEAN meratifikasi CISG $^{16}$ atau memperbaharui hukum kontrak nasionalnya

13 Wayne R. Barnes, Contemplating A Civil Law Paradigm for a Future International Commercial Code, (Lousiana Law Review 677, 2005), hlm. 76. Menurut Barnes sistem hukum yang paling banyak dipraktekan di dunia adalah civil law dan common law. Negara-negara yang mempraktekan sistem hukum ini ada yang secara penuh dan yang campuran. Indonesia dikategorikan menganut sistem hukum campuran, yaitu civil law, hukum adat dan hukum islam.

14 Upaya harmonisasi hukum kontrak dalam konteks internasional secara efektif dilakukan oleh lembaga atau organisasi internasional, baik yang sifatnya publik seperti Perserikatan Bangsa-Bangsa (PBB) dengan badan kelengkapannya seperti United Nations Commission on International Trade Law (UNCITRAL) atau organisasi internasional yang independen seperti International Institute for the Unification of Private Law atau Institut International Pour L'unification Du Droit Prive yang lazim dikenal dengan UNIDROIT. Peran yang dilakukan oleh berbagai organisasi internasional ini adalah mengeluarkan berbagai perjanjian atau kesepakatan internasional yang dapat dijadikan pedoman dalam penyusunan kontrak internasional. Dalam hal ini UNCITRAL telah mengeluarkan 1980 - United Nations Convention on Contracts for the International Sale of Goods (CISG) dan UNIDROIT telah mengeluarkan UNIDROIT Principles of International Commercial Contracts (UPICCS) pada tahun 1994 yang kemudian telah direvisi beberapa kali dan terakhir tahun 2010.

15 Berbagai pendekatan dikaji diantaranya adalah ASEAN membuat sendiri sebuah binding treaty on ASEAN contract law yang bersifat hard law atau membuat sebuah Model Law yang sifatnya persuasif (soft law).

16 Satu-satunya negara anggota ASEAN yang telah meratifikasi CISG adalah Singapura. 
dengan merujuk pada CISG. Disamping itu, ASEAN memberikan alternatif kepada anggotanya untuk memanfaatkan UNIDROIT Principles of International Commercial Contracts (UPICCS) sebagai referensi bagi pembaruan hukum kontrak nasionalnya. Nampak disini bahwa pendekatannya adalah bersifat persuasif dengan memberikan keleluasaan kepada Negaranegara anggota ASEAN untuk memperbarui atau membuat hukum kontrak nasionalnya dengan mengacu kepada perangkat atau instrument internasional yang ada yang diyakini merupakan best contracting practices atau yang diakui keberlakuannya secara universal.

Disamping itu, dapat dikatakan bahwa pendekatan yang dipilih adalah metoda harmonisasi dan bukan unifikasi. ${ }^{17}$ Walaupun merekomendasikan untuk meratifikassi CISG, yaitu agar terwujudnya suatu unifikasi di bidang hukum kontrak, khususnya kontrak jual beli barang internasional, namun ASEAN memberikan kemungkinan kepada anggotanya untuk menggunakan pendekatan yang lebih lunak atau fleksibel yaitu melalui harmonisasi hukum, dengan menggunakan prinsip-prinsip hukum yang ada dalam CISG dan UPICCs sebagai rujukan dalam memperbaharui atau membuat hukum kontrak nasionalnya.

Untuk mempercepat pembaruan hukum kontrak Indonesia beberapa pihak mengusulkan agar Indonesia segera mengaksesi CISG. Pertimbangannya adalah diantaranya CISG me- rupakan hasil kompromi dari asas-asas hukum yang dianut dalam sistem hukum common law dan civil law dan disusun berdasarkan pada best practices dalam transaksi-transaksi perdagangan internasional, sehingga aksesi Indonesia ini akan berguna sebagai langkah modernisasi hukum perjanjian Indonesia, khususnya sebagai sumber asas-asas hukum kontrak jual beli barang internasional. Penulis berpendapat bahwa aksesi terhadap CISG adalah satu alternatif yang dapat diambil oleh pemerintah Indonesia, namun tindakan tersebut belum memberikan jawaban bagi pembaruan hukum kontrak nasional yang komprehensif karena CISG hanya mengatur satu jenis transaksi yaitu jual beli barang internasional. CISG tidak atau belum tentu dapat diterapkan pada jenis-jenis transaksi lain dalam perdagangan internasional seperti faranchise, distributorship, commercial agency countertrade, dan lain lain.

Disamping itu, tanpa aksesi terhadap CISG pun, dalam praktek di Indonesia ternyata CISG sudah sering berlaku terhadap kontrak-kontrak dagang internasional ketika para para pihak dalam kontrak sepakat untuk menggunakan CISG sebagai governing law atas kontrak mereka, atau berlakunya CISG berdasarkan kaedah aturan hukum perdata internasional (conflict of law rules). Di sisi lain, CISG memberikan kebebasan, tidak saja kepada Negara-negara yang meratifikasi atau mengaksesi, tetapi juga bagi pihak-pihak dalam kontrak jual beli, untuk mengesampingkan berlakunya asas-asas yang

17 Lihat Huala Adolf, Hukum Perdagangan Internasional (Jakarta: Rajawali Pers, 2011). 31-32. Menurut Huala Adolf istilah "unifikasi" dan "harmonisasi" hukum sebenarnya memiliki makna yang sama, yaitu sebagai upaya penyeragaman substansi pengaturan dari sistem hukum yang ada. Perbedaan kedua istilah tersebut hanya terletak pada derajat upaya penyeragaman yang dilakukan. Penyeragaman melalui unifikasi dilakukan lebih dalam dibandingkan melalui harmonisasi. Cakupan unifikasi meliputi penghapusan dan penggantian atas suatu sistem hukum yang ada dengan suatu sistem hukum yang sama sekali baru. Berbeda dengan unifikasi, harmonisasi diartikan sebagai proses-proses dalam rangka untuk menghindari konflik dan menghasilkan perimbangan. Tujuan utama harmonisasi hukum hanya berupaya mencari kesergaman atau titik temu dari prinsip-prinsip yang bersifat fundamental dari berbagai sistem hukum yang ada. 
ada di dalamnya. Dengan demikian, CISG yang seharusnya berfungsi sebagai hard law, tetapi di sana-sini dilengkapi dengan ketentuanketentuan yang "melemahkan" daya ikatnya. ${ }^{18}$ Oleh karena itu menjadi pertanyaan bagi kita mengenai urgensi Indonesia untuk mengaksesi CISG. Yang lebih baik dilakukan Indonesia adalah menjadikan CISG sebagai model law untuk merombak, menambah, dan menyempurnakan Buku III Bab V tentang Perjanjian Jual Beli, dengan penyesuaian-penyesuan untuk jual beli domestik dan internasional. Pendekatan ini tentu masih sejalan dengan rekomendasi yang dibuat oleh ASEAN dalam upaya harmonisasi hukum kontrak nasional di Negara-negara ASEAN.

Selain menjadikan CISG sebagai model dalam pembaruan hukum kontrak Indonesia, dan sesuai dengan pendekatan yang direkomendasikan oleh ASEAN, Indonesia dapat menggunakan UPICCS sebagai referensi bagi pembaruan hukum kontraknya. Berbeda dengan CISG yang secara khusus mengatur tentang jual beli barang internasional, UPICCs memuat prinsip-prinsip atau asas-asas hukum kontrak internasional yang bersifat umum yang dapat diterapkan untuk semua jenis transaksi internasional.

UPICCS dianggap berhasil merumuskan kembali keseluruhan asas, aturan dan standar kontrak-kontrak perdagangan internasional pada umumnya, dan menyesuaikannya dengan best practices yang berkembang dalam bisnis dan perdagangan internasional. ${ }^{19}$ Sebagai sebuah Restatement of International Contract Law, UPICC pada dasarnya disediakan sebagai option untuk dipilih oleh pihak-pihak pembuat kontrak dengan menyatakannya secara tegas di dalam klausula pilihan hukum sebagai the governing law bagi kontrak mereka. UPICC memuat 211 Articles yang ditata di dalam sebelas Bab ${ }^{20}$ secara sistematik dan mencakup seluruh siklus-hidup sebuah kontrak (dari Formation s/d discharge), termasuk penyimpangan-penyimpangan yang mungkin terjadi dalam pelaksanaannya (non-performance, hardship, assignments, set-off, termination, dsb).

Selama perjalanan 18 tahun UPICC dipublikasikan kepada umum, berbagai perkembangan serta kebutuhan baru dalam praktik berkontrak secara internasional ditambahkan dan dijadikan dasar untuk penyempurnaan setiap edisi. Yang lebih penting lagi, asas-asas dan aturan-aturan di dalamnya tidak saja digunakan sebagai "the chosen legal system" oleh para pihak dalam kontrak, tetapi juga dijadikan referensi oleh forum-forum arbitrase perdagangan internasional dan pengadilan berbagai negara di dunia dalam memberikan dasar hukum atas keputusan-keputusan hukum yang dibuat. Pengakuan terhadap manfaat UPICC juga terbukti dari kenyataan bahwa UPICC telah diterjemahkan secara resmi ke dalam beberapa bahasa, dan proses penerjemahan ke dalam bahasa Indonesia juga dewasa ini sedang berlangsung.

Pembukaan (Preamble) dari UPICC menegaskan 6 (enam) tujuan utama penerbitan UPICC (Purpose of the Principles). Walaupun tujuan utama adalah "... to be applied when the parties have agreed that the contract be governed by them" dan tujuan penting lain adalah "... they

18 Bayu Seto Hardjowahono, UNIDROIT Principles on International Commercial Contracts dan Relevansinya bagi Pembaruan hukum Kontrak Indonesia, (Makalah disampaikan pada Forum Harmonisasi hukum Nasional dan Hukum Internasional, BPHN, 7 Maret 2012).

19. Lihat Michael Joachim Bonell, an International Restatement of Contract Law, the UNIDROIT Principles of International Commercial Contract (USA: Transnational Publishers, Inc, 2005), hlm. 35.

20 Edisi Pertama diterbitkan pada tahun 1994, edisi Kedua terbit pada tahun 2004, dan edisi Ketiga terbit pada tahun 2011 (disebut UNIDROIT Principles 2010). 
may be applied when the parties have not chosen any law to govern their contract", namun dalam konteks tulisan ini tujuan UPICC yang menjadi penting adalah bahwa UPICC "... may serve as a model for national and international legislators.

Dengan memperhatikan salah satu tujuan dari pembuatan UPICCs, maka penulis cenderung untuk berpandangan bahwa pembaruan hukum kontrak Indonesia sebaiknya mengacu pada UPICC sebagai Model Law, disertai dengan modifikasi-modifikasi serta tambahantambahan yang dianggap perlu untuk tetap dapat dipergunakan sumber hukum kontrak domestik dan transaksi-transaksi dan kontrak-kontrak perdagangan internasional. Penggunaan UPICCs sebagai model bagi pembaharuan hukum kontrak Indonesia akan juga sekaligus mengharmoniskan hukum kontrak nasional Indonesia dengan hukum kontrak Negara-negara anggota ASEAN lainnya, atau setidak tidaknya asas, aturan dan standar hukum kontrak Indonesia ke depan akan compatible dengan kontrak-kontrak perdagangan di kawasan ASEAN.

\section{Ruang Lingkup Perubahan}

Diskusi mengenai ruang lingkup perubahan hukum perjanjian yang terdapat dalam Buku III KUHPerdata cukup beragam. Sebagaimana diuraikan di bagian depan dari tulisan, tampak bahwa ada keinginan untuk mengganti secara keseluruhan Buku III KUHPerdata tentang Perikatan. Ini berarti bukan saja mengganti atau merubah ketentuan hukum perikatan yang lahir dari perjanjian (kontrak), tetapi juga ingin mengantikan ketentuan mengenai perjanjian yang lahir dari undang-undang, perikatan pada umumnya, hapusnya perikatan dan perjanjian tertentu. Namun ada pula perubahan yang diinginkan hanya mencakup asas-asas hukum kontrak dan beberapa jenis perjanjian tertentu, seperti kontrak baku, kontak pemerintah dan kontrak internasional.

Menjadi pertanyaan sampai sejauh mana lingkup perubahan hukum kontrak yang harus dilakukan sekarang ini dalam menghadapi perkembangan perdagangan internasional dan secara khusus perkembangan perdagangan dikawasanASEAN. Komitmenuntukmewujudkan harmonisasi hukum ASEAN tampaknya sudah menjadi sesuatu "diujung jalan". Sebelum, atau setidak-tidaknya bersamaan dengan upaya harmonisasi hukum regional itu, Indonesia harus mulai untuk mempercepat proses penyempurnaan hukum kontrak nasionalnya.

Dengan argumentasi bahwa pembaruan hukum kontrak Indonesia harus sejalan dengan arah perkembangan harmonisasi hukum kontrak ASEAN, maka lingkup perubahan sebaiknya hanya menyangkut prinsip prinsip dan ketentuan-ketentuan umum hukum perjanjian (general principles and rules on contracts). Dengan melihat pesatnya perkembangan transaksi jual beli internasional, dan berdasarkan rekomendasi ASEAN untuk mengadopsi CISG, perubahan dapat juga dilakukan terhadap Buku III Bab V mengenai Jual Beli. Dengan demikian maka perubahan akan fokus pada Buku III, Bab I (Perikatan pada Umumnya) Bagian I (Ketentuan Umum), Buku III, Bab II (mengenai Perikatan yang lahir dari perjanjian), (Bagian 1 mengenai Ketentuan Umum), Bab V (Jual Beli). Perubahan parsial dari Buku III KUHPerdata tersebut didasarkan juga pada alasan praktis, yaitu sisa waktu yang ada untuk mempersiapkan perubahan sangat terbatas, yaitu hanya tinggal 3 tahun lagi sebelum terbentuknya Masyarakat Ekonomi ASEAN tahun 2015.

Berkaitan dengan perubahan yang menyangkut prinsip-prinsip atau asas-asas hukum kontrak, Indonesia dapat menggunakan 
asas-asas yang terdapat dalam UPICCs. Asasasas dan aturan-aturan hukum kontrak yang dituangkan di dalam UPICC cukup memadai untuk memenuhi kebutuhan perubahan yang diinginkan. Disamping UPICC, beberapa prinsip hukum kontrak juga dapat diperoleh dari referensi lain, misalnya CENTRAL List of Lex Mercatoria Principles, Rules And Standards, dan Principles of European Contract Law. Secara umum ada beberapa prinsip hukum kontrak yang hampir selalu ada dalam setiap sistem hukum, yaitu: prinsip freedom of contract (party autonomy), prinsip pacta sunt servanda, good faith, kekuatan mengikat dari praktek kebiasaan dan prinsip overmacht atau impossibility of performance. ${ }^{21}$

Pengaturan prinsip prinsip serta aturan umum hukum kontrak dalam perubahan hukum kontrak Indonesia, disamping untuk mempermudah penyelarasan dengan praktek kontrak internasional juga harus mampu mengakomodasi perkembangan-perkembangan dalam transaksi-transaksi bisnis serta kontrakkontrak yang bersifat transnasional dan/atau mengandung unsur-unsur asing. Dalam kaitan ini, pengembangan asas-asas dan aturan umum hukum kontrak harus senantiasa dilandasi kesadaran bahwa ia harus memiliki tingkat aplikabilitas dan fleksibilitas yang baik untuk diterapkan baik pada kontrak-kontrak yang sepenuhnya bersifat domestik maupun yang mengandung unsur-unsurtransnasional. Prinsip- prinsip tersebut juga harus dapat menjadi pegangan agar terwujud tingkat keseragaman serta untukmengakomodir kepentingan kontrak/ perjanjian yang bersifat lintas sektoral. ${ }^{22}$

\section{E. Penutup}

\section{Kesimpulan}

Sebagaimana pepatah "sekali mendayung dua tiga pulau terlampaui", pembaruan hukum kontrak nasional Indonesia harus sekaligus dilakukan dalam kerangka harmonisasi hukum kontrak ASEAN. Oleh karena itu, metoda pendekatan dan lingkup substansi pengaturan pembaruan hukum kontrak Indonesia harus memperhatikan konsep harmonisasi hukum kontrakASEANyangada. Berbeda dengan konsep Uni Eropa yang menggunakan pendekatan hard law - yaitu dengan membuat European Contract Law, ASEAN cenderung menggunakan pendekatan soft law dengan meminta anggotanya menyusun atau memperbarui hukum kontraknya nasional masing masing dengan menggunakan instrument hukum internasional yang ada seperti CISG dan UPICCs sebagai model law. Pendekatan ini memberikan keleluasaan bagi Negara anggota ASEAN untuk mengadopsi atau mengambil alih prinsip/asas dan aturan hukum dari CISG dan UPICCS yang dianggap perlu dan sesuai kebutuhan dari masing masing Negara anggota.

Dalam memperbarui hukum kontrak nasional Indonesia, Indonesia dapat mempergunakan

21 Uraian mengenai prinsip prinsip tersebut lihat Huala Adolf, Dasar-Dasar Hukum Kontrak Internasional, (Bandung: Refika Aditama, 2010), hlm. 19-29.

22 Hukum kontrak untuk sektor tertentu adalah hukum yang materi muatannya mengatur juga mengenai kontrak misalnya adanya Undang-Undang tentang Larangan Praktik Monopoli dan Persaingan Usaha tidak sehat, UndangUndang tentang Penanaman Modal, Undang-Undang tentang Perseroan Terbatas, Undang-Undang tentang Mineral dan Batubara, Undang-Undang tentang Perlindungan Konsumen, dan peraturan perundang-undangan sektoral lainnya yang dalam materi muatannya diatur juga mengenai kontrak/perjanjian, misalnya Peraturan Pemerintah tentang Waralaba. Pembaruan hukum kontrak secara sektoral memang memberikan kepastian hukum dalam sektor terkait. Namun tetap diperlukan prinsip-prinsip serta aturan umum hukum kontrak 
UPICCS sebagai model law bagi bagi pengaturan hukum perjanjian secara umum, terutama menyangkut asas-asas dan aturan umum hukum kontrak internasional. Terhadap CISG, Indonesia dapat mempertimbangkan untuk meratifikasi konvensi tersebut, namun akan dirasakan lebih bermanfaat apabila prinsip atau asasasas yang ada dalam CISG diadopsi ke dalam hukum kontrak Indonesia, khususnya bagi pengaturan kontrak jual beli. Untuk saat ini, pembaruan yang terbatas pada prinsip-prinsip dan aturan umum hukum kontrak ditambah pengaturan kontrak jual beli dirasakan cukup memadai untuk mengantisipasi perkembangan transaksi-transaksi bisnis di kawasan ASEAN menjelang lahirnya Masyarakat Ekonomi ASEAN tahun 2015. Perubahan terbatas yang hanya menyangkut prinsip dan aturan umum hukum kontrak menjadikan hukum kontrak Indonesia ke depan akan lebih compatible dengan hukum kontrak nasional Negara Negara ASEAN lainnya dan dengan hukum kontrak internasional yang berlaku di belahan dunia lainnya. Selain itu, undang-undang hukum kontrak tersebut dapat menjadi undang-undang payung bagi pengaturan lebih lanjut kontrak-kontrak jenis tertentu yang dibuat dimasa depan.

\section{Saran-saran}

Diharapkan agar penyusunan hukum kontrak Indonesia dapat dijadikan prioritas dalam legislasi nasional dengan memasukan RUU Hukum Kontrak ke dalam Prolegnas 2015-2019, dan pembahasannya di Dewan Perwakilan Rakyat sudah dapat dilakukan selambatlambatnya tahun 2015 (sebagai prioritas tahun 2015).

Indonesia sebagai anggota UNIDROIT sejak tahun 2008 perlu meminta bantuan teknis ketika menyusun undang-undang kontrak sehingga dapat menerapkan UPICCs secara benar dan sesuai dengan maksud yang dikehendaki oleh pasal-pasal UPICCs tersebut. Bantuan teknis oleh UNIDROIT kepada anggotanya sudah jamak dilakukan seperti kepada Negara-negara Afrika (yang tergabung dalam OHADA) dan China ketika mereka menyusun hukum kontraknya.

Sekalipun secara prinsip CISG dan UPICCs digunakan sebagai model atau referensi dalam pembaruan hukum kontrak Indonesia, hukum adat tentang jual beli dan juga hukum islam yang masih relevan harus tetap diperhatikan dalam penyusunan undang-undang hukum kontrak yang baru. Demikan pula, walaupun pembaruan hukum kontrak Indonesia dimaksudkan dalam kerangka mengantisipasi perkembangan perdagangan internasional, dan secara khusus dalam kerangka lahirnya Masyarakat Ekonomi ASEAN tahun 2015, penyusunan hukum kontrak yang baru nanti harus tetap berorientasi kepada kepentingan nasional.

\section{DAFTAR PUSTAKA}

\section{Buku}

Adolf, Huala, Dasar-Dasar Hukum Kontrak Internasional, (Bandung: Refika Aditama, 2010).

Adolf, Huala, Hukum Perdagangan Internasional (Jakarta: Rajawali Pers, 2011).

Bonell, Michael Joachim, an International Restatement of Contract Law, the UNIDROIT Principles of International Commercial Contract (USA: Transnational Publishers, Inc, 2005).

Prodjodikuro, Wirjono, Asas-Asas Hukum Perjanjian (Bandung: Mandar Madju, 2000).

Sunandar, Taryana, Prinsip Prinsip UNIDROIT Sebagai Sumber Hukum Kontrak dan Penyelesaian sengketa (Jakarta: Sinar Grafika, 2004).

Taufiqurrahman, Karakter Pilihan Hukum, Kajian tentang Lingkup Penerapan the United Nations Convention on Contracts for the International Sale of Goods (CISG) 1980 (Surabaya: Bayumedia, 2010). 
Makalah / Artikel / Prosiding / Hasil Penelitian

Allan D. Rose A.O, The Challenges for Uniform Law in the Twenty-First Century, (Uniform Law Review, NS-Vol.1, 2005).

Bayu Seto Hardjowahono, UNIDROIT Principles on International Commercial Contracts dan Relevansinya bagi Pembaruan hukum Kontrak Indonesia, (Makalah disampaikan pada Forum Harmonisasi hukum Nasional dan Hukum Internasional, BPHN, 7 Maret 2012).
Wayne R. Barnes, Contemplating A Civil Law Paradigm for a Future International Commercial Code, (Lousiana Law Review 677, 2005).

Naskah Akademik Peraturaan Perundang-undangan tentang Hukum Perikatan, BPHN, Departemen Kehakiman RI, 1976/1977.

Naskah Akademik tentang Kontrak di Bidang Perdagangan, BPHNDepartemen Kehakiman, 1994. 